екон. наук : спец. 08.01.01 «Економічна теорія та історія економічної думки» / I. O. Знаменський. - Київ, 2009. - 20 с.

2. Белоусов А.Р. Эволюция системы воспроизводства российской экономики: от кризиса к развитию / Белоусов А.Р. - М.: Пресс, 2006. $-396 \mathrm{c}$.

3. Олейникова И. $\mathrm{H}$. Воспроизводственный процесс в системе региональной экономики: инновационная составляющая и механизм управления / Олейникова И. Н. - Ростов н/Д: Терра, 2004. $462 \mathrm{c}$.

4. Омелянович М. Ю. Економічні умови відтворювального розвитку підприємств: дис... канд. екон. наук: 08.06.01 / Михайло Юрійович Омелянович. - Донецьк, 2006. - 185 с.

5. Водачек Л. Стратегия управления инновациями на предприятии: Сокр. пер. со словац. / Авт. предисл. В.С. Рапопорт / Л. Водачек, О. Водачкова - М.: Экономика, 1989. $-167 \mathrm{c}$.

6. Чекаловець В.І.Реструктуризація портового господарства України: проблеми, принципи та основні напрямки / B.I.

Чекаловець, І.М. Олефір, О.Г. Пустовіт // Економіст. -2004. -№ 2. -С. 42-45.

7. Примачев Н.Т. Управление изменениями экономического потенциала морского транспортного комплекса [Електронний ресурс] / Н. Т. Примачев, А. Ф. Дмитриенко // Вісник економіки транспорту i промисловості. - 2013. - Вип. 43. - С. 57-61. Режим доступу: http://nbuv.gov.ua/jpdf/Vetp_2013_43_12.pdf

8. Кибик О.Н. Предприятия портовой деятельности: развиваемся по системе / О.Н. Кибик, А.В. Кравченко // Судоходство. -2007. № 7-8 (120). - - . 45-47.

9. Впровадження інновацій на промислових підприємствах. - Офіційні дані Державного комітету статистики України [Електронний ресурс]. - Режим доступу: http://www.ukrstat.gov.

http://www.ukrstat.gov.ua/operativ/operativ2005/ni /ind_rik/ind_u/2002.html

10. Транспортна стратегія України на період до 2020 року [Електронний ресурс]. Режим доступу: http://zakon2.rada.gov.ua/laws/show /2174-2010$\% \mathrm{D} 1 \% 80$

11. Програма розвитку інвестиційної та інноваційної діяльності в Україні: Затв. Постановою Кабінету Міністрів України від 2 лютий 2011 року № 389 // Офіційний вісник України від 22.04.2011. - 2011 р. - № 28 - ст. 1173.

12. Державна підтримка розвитку морегосподарського комплексу України (організаційні та правові аспекти): монографія / [О.М. Кібік, О.П. Подщерковний, Ю.З. Драпайло, В.А. Котлубай та ін.]; за ред. О.М. Кібік, О.П. Подцерковного. - Херсон: ФОП Грінь Д.С., 2014. - 442 с.

УДК: 665.6:330.325

\title{
ВИБІР МЕТОДУ ФІНАНСУВАННЯ ІНВЕСТИЦІЙНИХ ПРОЕКТІВ НАФТОПЕРЕРОБНОГО ПІДПРИЕМСТВА
}

\author{
Опікунова Н. В., доцент, \\ Лопата В. Г. студентка (ХНУБА)
}

У статті розглядається питання вибору методу фінансування інвестиційних проектів нафтопереробного підприємства. Всі підприємства в тій чи інший мірі пов'язані з інвестиційною діяльністю, що в свою чергу актуалізує питання коректного оцінювання методів фінансування інвестиційних проектів. Був запропонований розгляд таких питань, як карта проблеми підприємства, побудова дерева иілей вирішення проблеми, поділ підприємств

(C) Опікунова Н.В.,

Лопата В.Г.

Вісник економіки транспорту і промисловості № 51, 2015 
на чотири групи, щзо дозволило визначити залежність методу фінансування інвестиційних проектів нафтопереробного підприємства України від форми власності иъього підприємства та краӥни походження контролюючого акціонера, а отюе ефективність методу фінансування.

Ключові слова: інвестиційна діяльність, карта проблеми, дерево цілей, методи фінансування інвестиційних проектів, форма власності.

\title{
ВЫБОР МЕТОДА ФИНАНСИРОВАНИЯ ИНВЕСТИЦИОННЫХ ПРОЕКТОВ НЕФТЕПЕРЕРАБАТЫВАЮЩЕГО ПРЕДПРИЯТИЯ
}

\author{
Опекунова Н. В., доцент, \\ Лопата В. Г. студентка (ХНУСА)
}

В статье рассматривается вопрос выбора метода финансирования инвестиционных проектов нефтеперерабатывающего предприятия. Все предприятия в той или иной степени связаны с инвестиционной деятельностью, что в свою очередь актуализирует вопрос корректного оценивания методов финансирования инвестиционных проектов. Было предложено рассмотрение таких вопросов, как карта проблемы предприятия, построение дерева иелей решения проблемы, разделение предприятий на четыре группы, что позволило определить зависимость метода финансирования инвестиционных проектов нефтеперерабатывающего предприятия Украины от формы собственности этого предприятия и страны происхождения контролирующего акиионера, а следовательно эффективность метода финансирования.

Ключевые слова: инвестиционная деятельность, карта проблемы, дерево целей, методы финансирования инвестиционных проектов, форма собственности.

\section{THE CHOICE OF METHOD OF FINANCING INVESTMENT PROJECTS OF REFINERIES}

\author{
Opikunova N. V., docent, \\ Lopata V. G., student (Kharkov National University of Construction and Architecture)
}

The article discusses the choice of the method of financing investment projects refinery. Updates the existing material and technical base, increasing production, developing new activities all of this makes it necessary investment. The value of economic analysis for planning and implementation of investment activity can not be overestimated. Therefore actualized the issue of effective evaluation methods of financing investment projects. Was proposed consideration of issues such as card problems enterprises, construction wood purposes of solving the problem, the division of enterprises into four groups, which allowed to determine the dependence of the method of financing investment projects of refineries Ukraine of ownership of the company and country of origin of the controlling shareholder, and hence the effectiveness of the method of financing .

Keywords: investment activity, map the problem, tree of objectives, methods of financing investment projects, ownership.

Постановка проблеми та ї зв'язки з науковими чи практичними завданнями. Інвестиції є основою розвитку підприємства. Ефективна інвестиційна діяльність підприємства $\epsilon$ основою сталого розвитку виробництва, науково-технічного і соціального прогресу. Інвестиційний проект являє собою комплекс взаємопов'язаних заходів, направлених на досягнення поставлених цілей в умовах обмежених фінансових ресурсів і часу. Оцінка ефективності та визначення методів фінансування інвестиційних проектів нафтопереробної галузі послідовний, виважений та дуже важкий шлях. Для цього доцільно буде розглянути таки питання, як карта проблеми підприємства, побудова дерева

Вісник економіки транспорту і промисловості № 51, 2015 
цілей вирішення проблеми, оцінка залежності методу фінансування від форми власності та країни походження контролюючого акціонера нафтопереробних підприємств.

\section{Аналіз останніх досліджень $i$}

публікацій. Проблеми оцінки і фінансування інвестиційних проектів нафтопереробних підприємств розглядали в своїх працях вітчизняні та зарубіжні науковці: Л.В. Баб'як[1], І. А. Бланк[2], Л.І. Губанова[3], Г.В. Кіщенко[4], О.М. Мацяк[1], М.Я. Топилко[1] та ін. Ними був зроблений істотний внесок у розробку теорії i практики оцінки i фінансування інвестиційних проектів нафтопереробних підприємств.

\section{Виділення невирішених}

частин загальної проблеми. Дослідження оцінки і фінансування інвестиційних проектів нафтопереробного підприємства потребує розгляду факторів, які впливають на прийняття рішень за інвестиційними проектами, розгляд карти проблеми, дерева цілей вирішення проблеми та знаходження залежності методу фінансування від форми власності та країни походження контролюючого акціонера нафтопереробних підприємств.

Формування цілей статmі. Цілями цієї статті є розгляд факторів, які впливають на прийняття рішень за інвестиційними проектами. Визначення ефективної оцінки i методу фінансування інвестиційних проектів, які б гарантували підприємству позитивні результати та досягнення цілей.

Виклад основного матеріалу дослідження. Всі підприємства у тій чи іншій мірі пов'язані 3 інвестиційною діяльністю. Прийняття рішень за інвестиційними проектами ускладнюється різними факторами, які представлені на рисунку 1 [2].

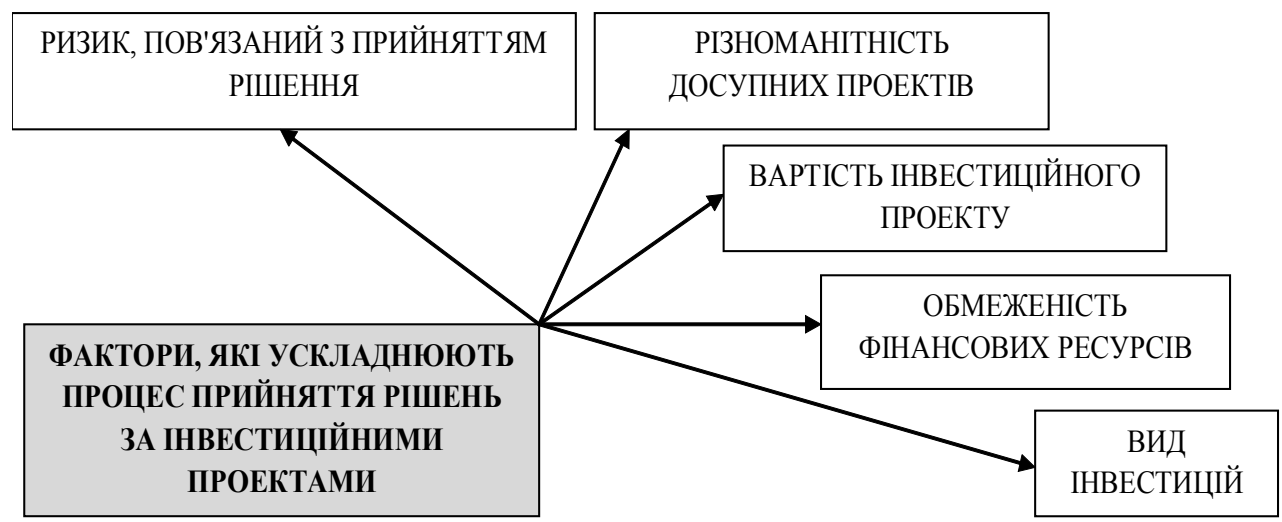

Рис. 1. Фактори ускладнення прочесу прийняття рішень за інвестиційними проектами [2]

Допущена помилка у виборі одного інвестиційного проекту 3 декількох альтернативних чи неправильний вибір методу фінансування проектів може призвести до значного падіння ефективності інвестиційної діяльності підприємства, уповільнення темпів модернізації, погіршення якості продукції тощо. Тому визначимо основні фактори негативного впливу на ефективність інвестиційної діяльності підприємств(рис.2).

Отже, побудуємо дерево цілей вирішення проблеми оцінки та фінансування альтернативних інвестиційних проектів нафтопереробного підприємства.

Дерево цілей представляє собою структуровану, побудовану за ієрархічним принципом (розподілену по рівнях, ранжованих) сукупність цілей вирішення визначеної наукової проблеми, де виділено генеральну мету («вершина дерева»), що полягає в удосконаленні системи оцінки та фінансування альтернативних інвестиційних проектів підприємства та підпорядковані ій підцілі кількох рівнів («гілки дерева ») (рис. 3) [3].

Вісник економіки транспорту і промисловості № 51, 2015 


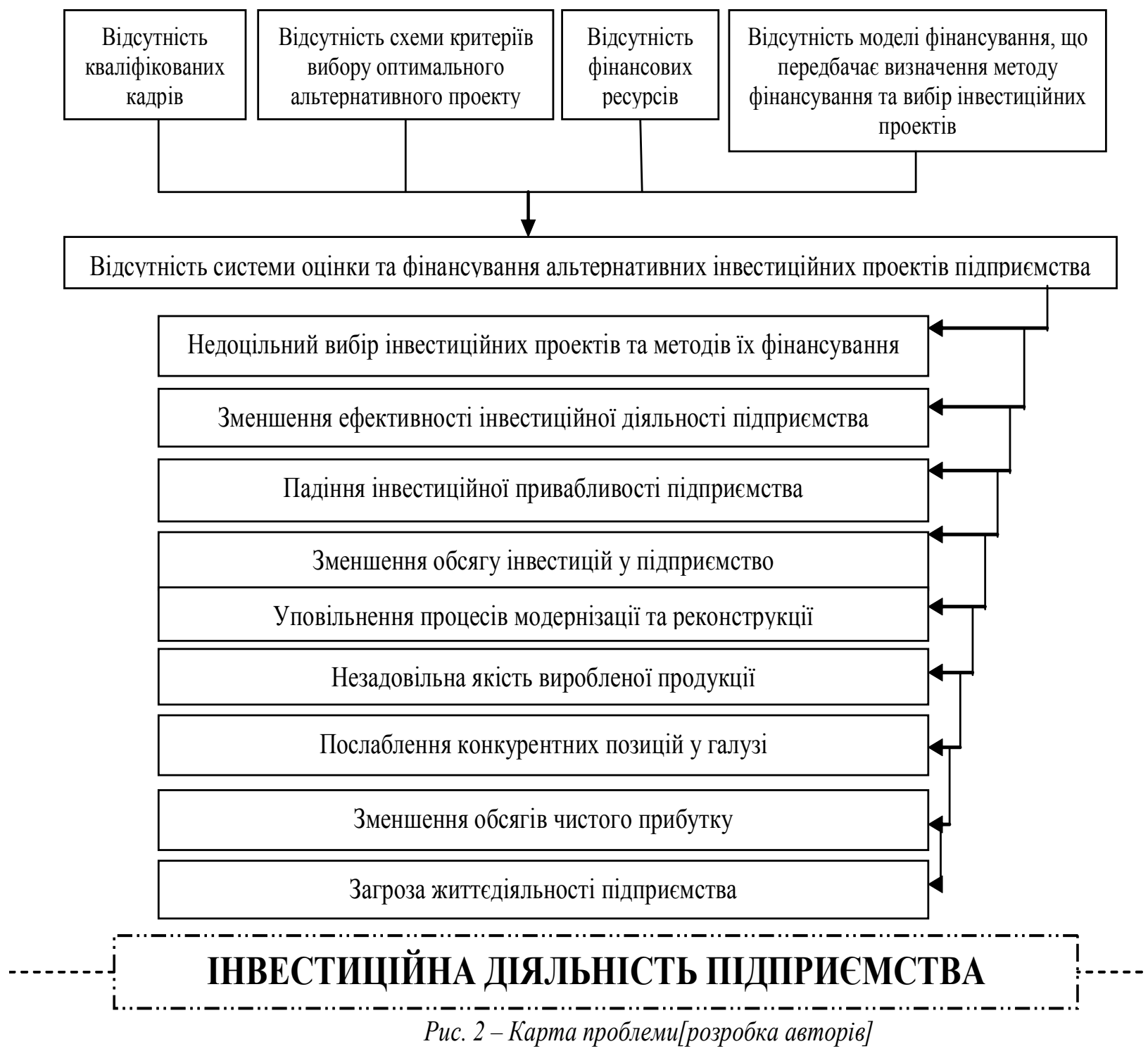

Також важливим аспектом у створенні моделі фінансування інвестиційних проектів $є$ іiі залежність від форми власності та країни походження контролюючого акціонера нафтопереробних підприємств[4]. Саме тому перейдемо до нафтопереробних підприємств нашої країни, яких шість на території України, та розглянемо методи фінансування країни базування контролюючого акціонера кожного українського НПЗ у таблиці 1[5].

Таким чином це дозволить врешті решт досягти головної мети - створити модель фінансування нафтопереробного підприємства, що передбачає визначення методу фінансування, оцінку ефективності і вибір альтернативних інвестиційних проектів. 


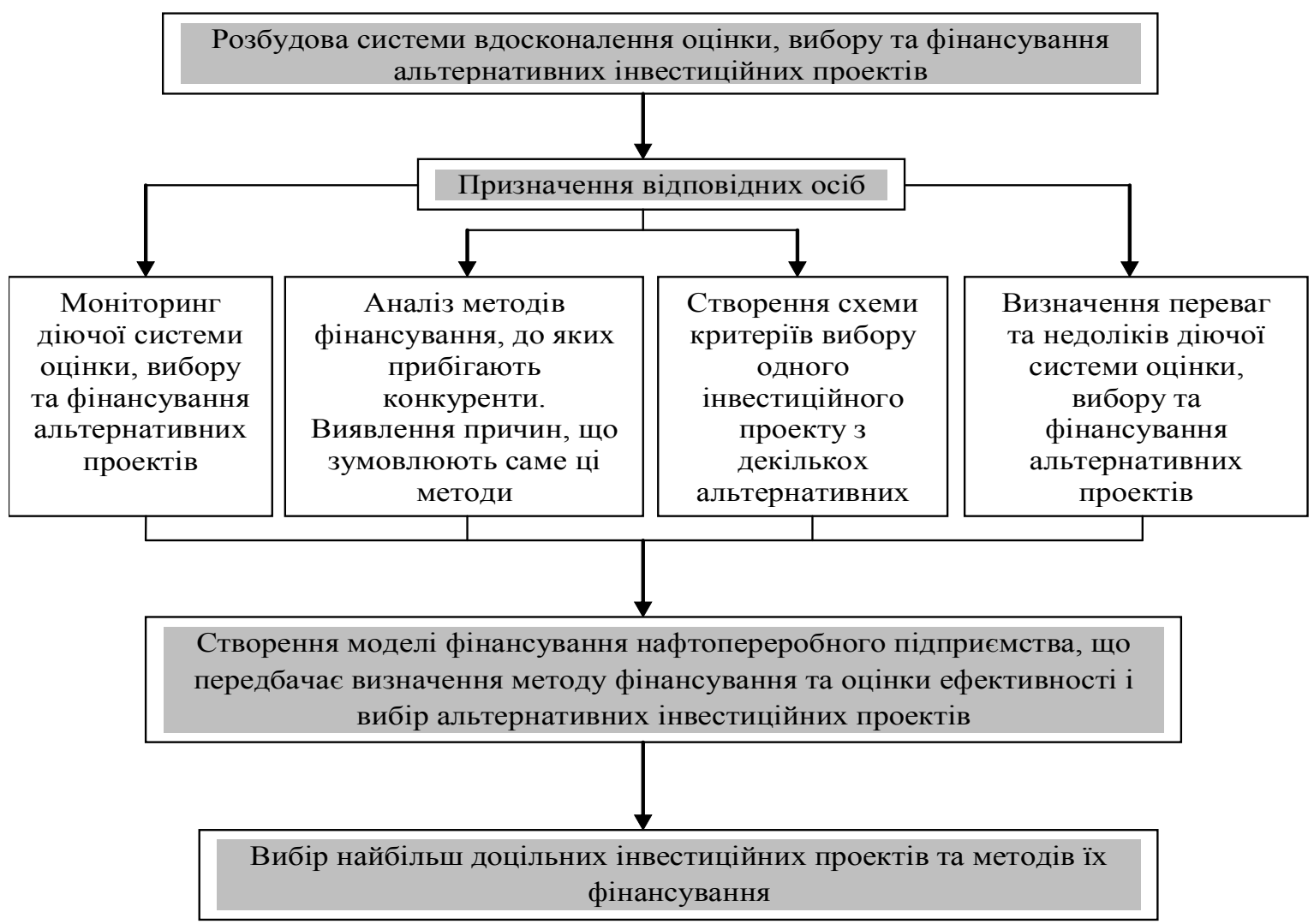

Рис. 3 - Дерево изілей[розробка авторів]

Характеристика нафтопереробних підприємств України

\begin{tabular}{|c|c|c|c|}
\hline № & Назва підприємства & Контролюючий акціонер & Короткий опис діяльності \\
\hline 1 & 2 & 3 & 4 \\
\hline 1. & $\begin{array}{c}\text { Дрогобицький НПЗ (ВАТ } \\
\text { «НАФОПЕРЕРОБНИЙ } \\
\text { КОМПЛЕКС - } \\
\text { ГАЛИЧИНА») }\end{array}$ & $\begin{array}{c}\text { Група «Приват» } \\
\text { (Україна). }\end{array}$ & $\begin{array}{l}\text { Дрогобицький НПЗ - третій } \\
\text { за потужністю НПЗ на Україні, } \\
\text { здатний переробити до } 3.5 \text { млн. } \\
\text { тонн нафти на рік. } \\
3 \text { метою реалізації плану } \\
\text { реконструкції підприємства для } \\
\text { досягнення якості моторних палив } \\
\text { відповідно до норм Євро-5 та } \\
\text { будівництва нових об'єктів, } \\
\text { необхідних для збільшення } \\
\text { глибини переробки нафти до } 97 \% \text {, } \\
\text { укладено ряд угод. } \\
\text { Щоб } \\
\text { реконструкцію профінансувати } \\
\text { Товариство залучає кредитні } \\
\text { кошти. }\end{array}$ \\
\hline
\end{tabular}


Продовження табл.. 1

\begin{tabular}{|c|c|c|c|}
\hline 1 & 2 & 3 & 4 \\
\hline 2. & $\begin{array}{c}\text { Надворнянський НПЗ } \\
\text { (Публічне акціонерне } \\
\text { товариство } \\
\text { «НАФТОХІМІК } \\
\text { ПРИКАРПАТТЯ») }\end{array}$ & $\begin{array}{c}\text { Фінансово-промислова } \\
\text { група «Приват» } \\
\text { (Україна) }\end{array}$ & 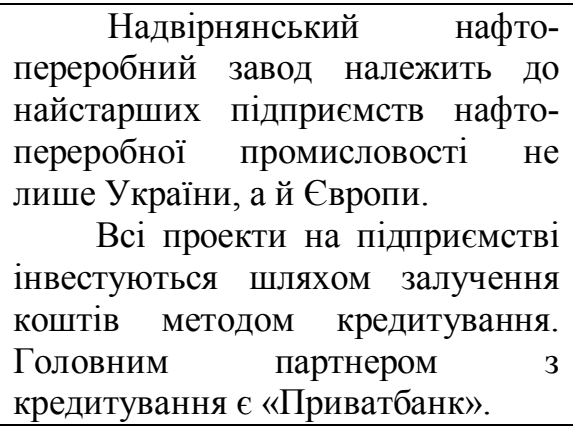 \\
\hline 3. & $\begin{array}{c}\text { Публічне акціонерне } \\
\text { товариство «ЛУКОЙЛ- } \\
\text { ОДЕСЬКИЙ } \\
\text { НАФТОПЕРЕРОБНИЙ } \\
\text { ЗАВОД» }\end{array}$ & $\begin{array}{l}\text { Компанія «Лукойл» } \\
\text { (Іноземний інвестор ) }\end{array}$ & \begin{tabular}{ll}
\multicolumn{3}{c}{ Одеський нафтопере-робний } \\
завод $\epsilon$ & передостаннім за \\
потужністю & на Україні, здатний \\
переробити & 2.8 млн. тонн нафти \\
на рік. & \\
Основним джерелом фінан- \\
сування на підприємстві є надання \\
позикових коштів Компанії "SLB \\
INVEST LIMITED".
\end{tabular} \\
\hline 4. & $\begin{array}{c}\text { Херсонський НПЗ } \\
\text { (ЗАТ«ХЕРСОНСЬКИЙ } \\
\text { НАФТОПЕРЕРОБНИЙ } \\
\text { ЗАВОД») }\end{array}$ & $\begin{array}{c}\text { Фінансово-промислова } \\
\text { група «Контініум» } \\
\text { (Україна) }\end{array}$ & 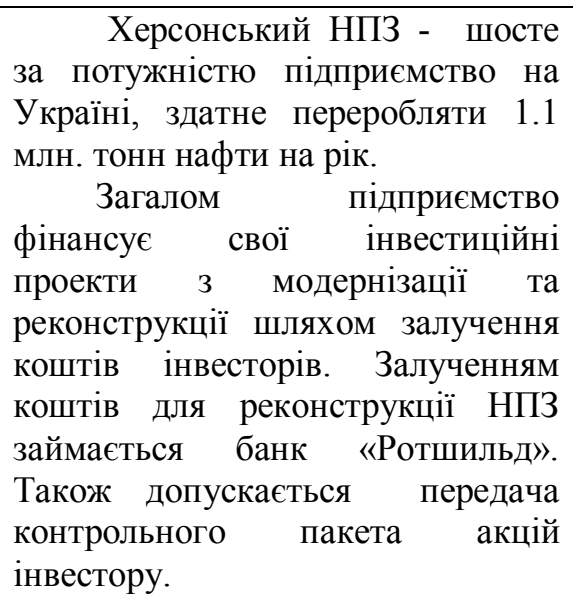 \\
\hline 5. & $\begin{array}{c}\text { Кременчуцький НПЗ } \\
\text { (Публічне акціонерне } \\
\text { товариство } \\
\text { "Транснаціональна } \\
\text { фінансово-промислова } \\
\text { нафтова компанія } \\
\text { "Укртатнафта") }\end{array}$ & $\begin{array}{c}\text { Компанія «Татнефть» } \\
\text { (Іноземний інвестор) } \\
\text { через російсько- } \\
\text { українське СП } \\
\text { «Укртатнафта» }\end{array}$ & 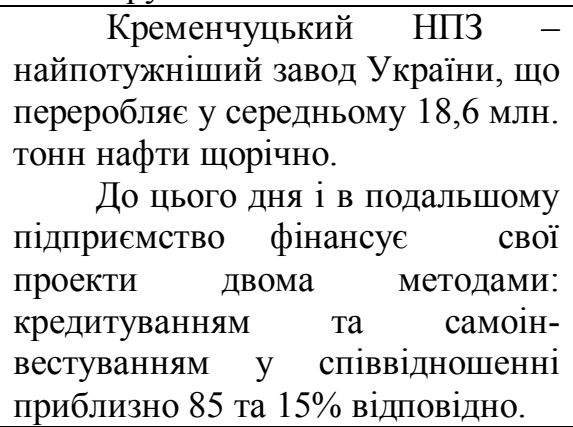 \\
\hline 6. & $\begin{array}{l}\text { Лисичанський НПЗ } \\
\text { (Приватне акціонерне } \\
\text { товариство «ЛІНИК») }\end{array}$ & $\begin{array}{c}\text { Холдінг «ТНК-ВР» } \\
\text { (Іноземний інвестор) }\end{array}$ & $\begin{array}{l}\text { За потужністю завод посягає } \\
\text { друге місце серед НПЗ країни. Він } \\
\text { переробляє } 8 \text { млн. тонн щорічно. } \\
\text { Майже всі інвестиційні } \\
\text { проекти на Лисичанському НПЗ } \\
\text { фінансуються } \\
\text { самоінвестування. } \\
\text { наменетор вкласти в українські активи має } \\
\text { в найближчі } 10 \text { років близько } 1 \\
\text { млрд дол. }\end{array}$ \\
\hline
\end{tabular}

Вісник економіки транспорту і промисловості № 51, 2015 
Зведемо отримані дані у рисунок 4. У стовпчиках НПЗ поділено за формою власності підприємства, у рядках - за країною походження контролюючого акціонера.
Виділяємо різними кольорами сектори таблиці залежно від методу фінансування інвестиційних проектів на підприємстві:

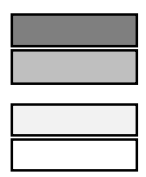

Переважно метод кредитування, частково - самофінансування;

Метод кредитування;

Метод самофінансування;

Метод інвестування (залучення інвесторів).

\begin{tabular}{|clc|}
\hline & \multicolumn{1}{c}{ ПАТ(ВАТ) } & ПАТ(ЗАТ) \\
Іноземні & 1.ПАТ «ЛУКОЙЛ-ОДЕСЬКИЙ & 1.ПАТ «ЛІНІК» \\
інвестори & НАФТОПЕРЕРОБНИЙ ЗАВОД» & \\
& 2.ПАТ «УКРТАТНАФТА & \\
Україна & 1.ВАТ «НАФТОПЕРЕРОБНИЙ & 1.ЗАТ «ХЕРСОНСЬКИЙ \\
& КОМПЛЕКС - ГАЛИЧИНА & НАФТОПЕРЕРРОБНИЙ \\
& 2.ПАТ «НАФТОХІМІК ПРИКАРПАТТЯ» & ЗАВОД» \\
& & \\
\end{tabular}

Рис. 4. Залежність методу фінансування від форми власності[розробка авторів]

Висновки даного дослідження $i$ перспективи подальших робіт у цьому напрямку. Всі підприємства в тій чи іншій мірі пов'язані 3 інвестиційною діяльністю. Тільки розуміння того в якому напрямку діяти, може привести до позитивної динаміки. Ретельний розгляд факторів впливу на прийняття рішень за інвестиційними проектами, виявлення залежності методу їх фінансування від форми власності підприємства та країни походження контролюючого акціонера та забезпечення ефективної оцінки i шляху фінансування інвестиційної діяльності гарантують підприємству очікувані результати та досягнення цілей.

\section{СПИСОК ЛІТЕРАТУРИ}

1. Баб'як Л.В.Стан i проблеми інноваційного розвитку нафтопереробних підприємств України [Текст] : // Л.В. Баб'як, О.М. Мацяк, М.Я. Топилко - Львів: Національний університет "Львівська політехніка". - 2009. - 478c.

2. Бланк I. А. Инвестиционный менеджмент [ учб. курс. ] / І. А. Бланк. - //К.: Ника-Центр : Эльга-Н. - 2001. - 11 с.

3. Губанова Л. І. Оцінка інвестиційних проектів / Л. І. Губанова // Фінанси України. 2001. - № 10. - 126-131c.

4. Кіщенко Г.В. Оцінювання внутрішніх та зовнішніх джерел фінансування підприємств (на прикладі нафтопереробної галузі) [Текст] : // Г.В. Кіщєнко - К.: Приватний вищий навчальний заклад «Европейський університет». - 2010. - 212с.

5. Характеристика нафтопереробних підприємств України: [Електронний ресурс]. Режим доступу: smida.gov.ua (дата звернення 29.09.2015).

Рецензент д.е.н., професор ХНУБА Чупир О.М. Експерт редакційної колегії к.е.н., дочент УкрДУЗТ Зубенко В.О. 